\title{
DOČKÁME SE UNIVERZÁLNÍ CHŘIPKOVÉ VAKCÍNY?
}

Jiří Patočka

11: $1-270,2009$

ISSN 1212-4117

Jihočeská univerzita v Českých Budějovicích, Zdravotně sociální fakulta, katedra radiologie a toxikologie

\section{ÚVOD}

Chřipka je infekční virové onemocnění, které každoročně postihuje velkou část světové populace a je pŕíćinou úmrtí desetitisíců lidí na celém světě. Je vysoce nakažlivá, postihuje všechny věkové skupiny a může vyvolat epidemii. Chřipka jako sezonní onemocnění se nejčastěji vyskytuje v zimních a jarních měsících. Původcem je chřipkový virus a zdrojem infekce je nakažený člověk nebo zvíre. K přenosu dochází kapénkovou infekcí - mluvením, kašláním, kýcháním apod.

\section{Klinický obraz chřipky}

Chřipka se projevuje jako prudký zánět dýchacích cest, který se po uplynutí krátké inkubační doby (12-48 hodin) projeví rychlým nástupem horečky, třesavkou, bolestmi hlavy, svalů, kloubů a pocitem schvácenosti. Chřipku doprovází suchý, dráždivý kašel, bolest v krku, často i bolest na hrudi. Nemocní někdy zvrací, jsou spaví, omámení a mohou mít halucinace, takže někdy bývá vysloveno podezření na zánět mozkových blan. $\mathrm{K}$ nejčastějším komplikacím patří zápal plic, zánět vedlejších nosních dutin, zánět středního ucha apod. $\mathrm{K}$ vzácnějším komplikacím patři zánět centrálního nervového systému nebo zánět srdce. U dospělých lidí s nějakou chronickou chorobou dojde zpravidla k jejímu zhoršení. Komplikacemi jsou nejvíce ohroženy malé děti a starší lidé (Beran, Havlík, 2007).

\section{Chřipkový virus}

Virus chřipky se vyskytuje ve třech odlišných typech, označovaných písmeny A, B a C. Typy A a B nejčastěji infikují člověka. Chřipkové viry typu A vyvolávají onemocnění i u některých zvírat, zatímco chřipkové viry typu $\mathrm{B}$ infikují výhradně člověka. Viry typu A i B každoročně podlehnou mírným genetickým mutacím. Po 20 až 30 letech dochází $\mathrm{k}$ zásadním změnám antigenů chřipkového viru typu $\mathrm{A}$, což bývá důvodem vzniku pandemií a velkých epidemií.

Chřipkové viry patří do čeledi Orthomyxoviridae, viry typu A a B jsou řazeny do rodu Influenzavirus a typ $\mathrm{C}$ je považován za zvláštní rod (Hongo, 2006). Viry tvoří sférické částice o průměru cca $80 \mathrm{~nm}$, složené z jádra, obalu a povrchových antigenů (obr. č. 1).

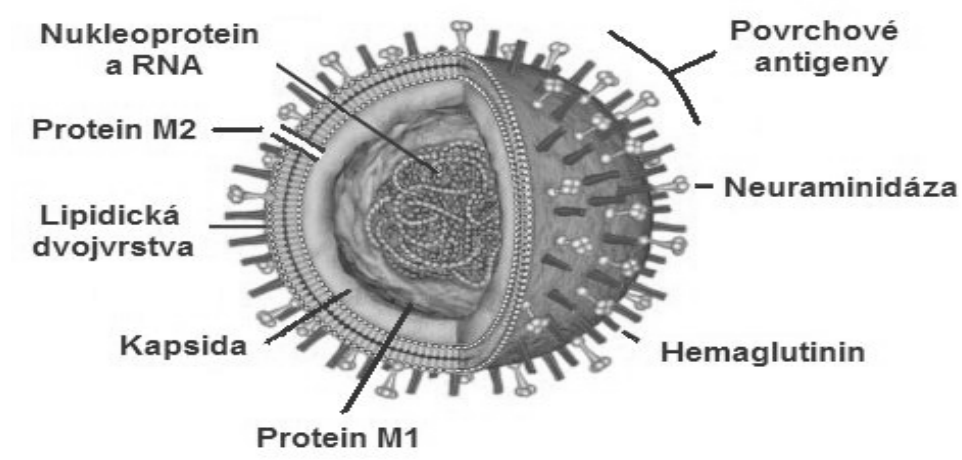


Jádro tvoří helikoidální kapsida, obsahující jednovláknovou RNA, obklopená nukleoproteinem (NP-antigen) (Hosaka, 1997). Ta je nositelkou dědičné informace chřipkového viru. Je složena z 8 genů, z nichž důležité pro schopnost viru vyvolat onemocnění jsou dva (Maesa et al., 2003). První z nich kóduje bílkovinu hemaglutinin $(\mathrm{H})$, která slouží k pronikání viru do buněk hostitele. Druhý gen kóduje enzym neuraminidáza $(\mathrm{N})$, s jehož pomocí se namnožený virus uvolní z infikované buňky. Další geny kódují nukleokapsidový protein (NP a membránové proteiny M1 a M2), které jsou druhově specifické a na rozdíl od povrchových glykoproteinů i relativně neměnné. Jsou společné všem subtypům a variantám jednoho druhu viru a podle jejich vlastností jsou chřipkové viry rozděleny na typy $\mathrm{A}, \mathrm{B}$ a $\mathrm{C}$.

Obal viru tvoři 8 koncentrických vrstev, které obklopují kapsidu. Vnitřní bílkovinná vrstva obalu je tvořena M1 proteinem. Tento protein stabilizuje virovou částici a je též důležitý pro maturaci virionu a jeho uvolňování z hostitelské buňky (Itoh, Hotta, 1997). Vnější povrch obalu tvoří lipidická dvojvrstva, která vzniká z cytoplazmatické membrány hostitelské buňky. Do obalu je dále vložen malý transmembránový protein M2, který plní funkci protonového kanálu (Betakova, 2007). Protein M2 prochází naprríč obalem a umožňuje vytvořit kyselé pH vnitřní části viru, když je uvnitř kyselého endozomu. Tento proces vede $\mathrm{v}$ konečné fázi $\mathrm{k}$ fúzi virového obalu s membránou endozomu a k uvolnění nukleokapsidy do cytoplazmy (Gray, Tamm, 1998).

Povrchové antigeny jsou součástí zevní vrstvy obalu chřipkového viru. Jsou tvořeny dvěma glykoproteinovými antigeny - hemaglutininem $(\mathrm{H})$ a neuraminidázou $(\mathrm{N})$. Tyto antigeny mají zásadní význam pro patogenezi nemoci (Harrison, 2008). Oba jsou velmi proměnlivé a podmiňují rozlišování antigenních subtypů a variant. Až dosud bylo identifikováno 16 různých typů hemaglutininů virů chřipky $\mathrm{A}$, které se označují pořadovými čísly $\mathrm{H} 1-\mathrm{H} 16$, a 9 různých typů neuraminidázy označovaných N1N9. U chřipkového viru typu B byl identifikován pouze 1 podtyp $\mathrm{H}$ a 1 podtyp $\mathrm{N}$.

Hemaglutinin dostal své jméno podle schopnosti aglutinovat červené krvinky různých živočišných druhů. Glykoprotein hematoglutininu má velikost asi $10 \mathrm{~nm}$ a skládá se ze dvou polypeptidových řetězců. Vizuálně vypadá jako trojhranolek (Bentz, Mittal, 2003). Prostřednictvím hemaglutininu se virion prrichycuje na povrchové receptory vnímavé buňky. Membránový receptor takové buňky musí obsahovat Nacetylmuramovou (sialovou) kyselinu).

Neuraminidáza nebo též sialidáza je lokalizována na povrchu viru mezi výběžky hemaglutininu. Tento protein hřibovitého tvaru má vlastnosti enzymu, který má schopnost štěpit $\mathrm{N}$ -acetylmuramovou kyselinu a přilehlou sacharidovou část glykoproteinů $\mathrm{v}$ povrchové vrstvě buněčné membrány.

V současnosti jsou nejrozšírenější antigenové varianty chřipkového viru typu $A$ variace H1N1 a H3N2. Existují však ještě další variace viru, a proto jsou specifické chřipkové kmenové oddíly identifikovány standardním názvoslovím, specifikujícím typ viru, geografickou polohu prvního výskytu viru, rok izolování, pořadové číslo izolování, a subtypy HA a NA (např. názvy jako A/Moscow/10/99 (H3N2) nebo B/ Hongkong/330/2001).

V minulém století došlo ke třem pandemiím chřipky typu A. V letech 1918-1919 to byla tzv. španělská chřipka způsobená typem H1N1, která usmrtila více než 50 milionů lidí, v letech 1957-1958 tzv. asijská chřipka, typ H2N2, která usmrtila asi 2 miliony lidí, a v letech 1968-1969 tzv. hongkongská chřipka, typ H3N2, která jen v USA má na svědomí 34 tisíc mrtvých.

Donedávna se předpokládalo, že člověk může být infikován jen virem s hemaglutininy typu H1, H2 nebo H3. Ptačí chřipkové viry s hemaglutininy $\mathrm{H} 4$ a $\mathrm{H} 5$ mély být proto pro člověka neškodné. V roce 1997 však byl zaznamenán první prríklad přímého přenosu ptačího chřipkového viru $\mathrm{H} 5 \mathrm{~N} 2 \mathrm{z}$ ptáka na člověka. Stalo se tak během epidemie ptačí chřipky $\mathrm{u}$ drůbeže v Hongkongu, kdy virus vyvolal těžké onemocnění dýchacích cest u 18 osob, z nichž 6 zemřelo. Od té doby byly zaznamenány i další príklady této lidské formy onemocnění. Během let 1983-1984 došlo k epidemii ve Spojených státech. Typ H5N2 způsobil sice úmrtí jen několika lidí, ale stal se vysoce patogenním a následně vyvolával až $90 \%$ úmrtnost. Tehdy bylo třeba zlikvidovat více než 17 milionů kusů ptactva. V letech 1998-2000 došlo $\mathrm{k}$ další epidemii $\mathrm{v}$ Itálii, kde patogenem byl typ H5N2 a H7N1 (De Marco et al., 2005). Zpočátku měl nízkou patogenicitu, ale následně během 
9 měsíců zmutoval do vysoce patogenní formy. Bylo třeba zlikvidovat více než 13 milionů kusů ptactva. Pokud by vypukla pandemie chřipky způsobená $\mathrm{H} 5 \mathrm{~N} 2$, odhaduje se, že by mohla usmrtit až 7 milionů lidí (Yamazaki et al., 2009). $\mathrm{V}$ současné době realizuje protipandemická opatření pouze 40 zemí. V ČR existuje „Pandemický plán“ zpracovaný hlavním hygienikem ČR, který se opírá o současný stav poznání v problematice antivirotik, tj. vypracování doporučení pro použití antivirotika Tamiflu ${ }^{\circledR}$ pro profylaktické i terapeutické využití v prípadě pandemie chřipky A H5N1 a použití prepandemické vakcíny.

V březnu 2008 proběhlo v Singapuru International Symposium on Respiratory Viral Infections. Součástí hlavního programu bylo vyhodnocení použití antivirotik u ptačí chřipky. Z jednání vyplynul jednoznačný závěr: Tamiflu ${ }^{\circledR}$ byl potvrzen a schválen pro postexpoziční profylaxi a léčbu ptači chřipky H5N1 u dospělých a dětí starších 1 roku. WHO při možném pandemickém šíření předpokládá podávání vyšších dávek Tamiflu ${ }^{\circledR}$ po delší dobu. Procento přežití nemocných zásadně ovlivňuje doba podání Tamiflu ${ }^{\circledR}$ od začátku manifestních příznaků. Nejvyšší benefit byl dosažen při podání v prvních 12-24 hodinách od manifestace prvních příznaků.

\section{Variabilita a rekombinace}

U virů typu A se kromě vysoké mutagenity vyskytuje i nebezpečná možnost rekombinace: pokud dva různé subtypy viru napadnou tutéž buňku, mohou si vyměnit část RNA a vytvořit radikálně odlišný virus se zcela novými vlastnostmi a patogenicitou (He et al., 2009). V tomto ohledu panují veliké obavy $\mathrm{z}$ kombinace chřipkového viru na územích, kde se setkává velké množství vodního ptactva a drůbeže s rozsáhlým chovem prasat. Jak dokazují události posledních let, typ viru H5N1 se mezi divokým ptactvem stále širíí, zejména mezi divokými kachnami, a prasata jsou infikovatelná jak ptačími, tak savčími typy viru. To zvyšuje pravděpodobnost náhodné rekombinace viru, který by mohl být nebezpečný člověku (Collins et al., 2008).

Kde virus chřipky mutuje a kde se schovává přes léto?

Chřipka je typickým sezonním onemocněním.
V mírném pásmu přichází chřipka obvykle v zimním období, na jaře vrcholí a v létě mizí. $\mathrm{V}$ zimě se virus vyvijí a mění své imunogenní vlastnosti a napadá velké množství lidí tím, že překonává jejich imunitu. $\mathrm{V}$ průběhu jara se však stahuje do ústraní a na celé léto zmizí, aby $\mathrm{s}$ př́chodem nové zimy vyrukoval s novými zbraněmi, které opět obelstí náš imunitní systém. Kde se však chřipkový virus skrývá mezi dvěma zimními obdobími? Kde a jak přežívá a jakým rafinovaným způsobem mění svou genetikou výzbroj? Viry nejsou schopny samostatné existence bez hostitelské buňky, tedy přesněji nejsou schopny se bez hostitelské buňky reprodukovat. Buňka jim slouží jako biologická továrna a sklad náhradních dílů potřebných pro vznik nových virů. Genetická analýza chřipkových virů $z$ jednotlivých let prokázala velké rozdíly v jejich genomu. To podporuje migrační teorii - kdyby se viry skrývaly na jednom místě, jejich genom by se nemohl př́liš změnit a imunitní systém našeho organismu by se $\mathrm{s}$ nimi snadno vypořádal. Zákeřnost chřipky však spočívá právě $\mathrm{v}$ tom, že virus si na nás přichystá pokaždé něco nového. Aby vědci zjistili, zda migrační hypotéza platí, analyzovali chřipkový genom 900 vzorků původců chřipkové epidemie z let 1998-2005 pocházejících z Nového Zélandu, Austrálie a New Yorku. Zjistili, že viry s určitým genomem nalezené $\mathrm{v}$ zimním období v New Yorku byly později nalezeny v Austrálii a na Novém Zélandu (Nelson et al., 2007). Předpokládá se, že tím místem, kde viry přezimují a kde dochází ke vzniku různých mutací chřipkového viru, je jihovýchodní Asie, kde lidé žijí v těsné blízkosti zvírat. Jednotlivé virové kmeny tak spolu prricházejí do kontaktu a mají možnost si vyměňovat části své genové výbavy. $\mathrm{V}$ dnešním světě, kde se vzdálenosti neuvěritelně zkrátily a jednotlivé země jsou čím dál lépe propojeny, je globální šíření viru usnadněno. Śírení chřipky je ale díky tomu více pod dohledem a usnadňuje to cestu k vývoji vakcíny, která bude účinná proti všem chřipkovým kmenům. Tento úkol však pro vědce zatím zůstává velkou výzvou.

\section{Strategie prrípravy chřipkových vakcín}

Nejlepší možnost prevence chřipky představuje očkování chřipkovou vakcínou. Př́prava vakcíny však není jednoduchá. Díky tomu, že se každoročně mění antigenní vlastnosti viru, je nutné 
každoročně připravovat vakcínu novou a každoročně také přeočkovávat obyvatelstvo. To neobyčejně zvyšuje náklady na boj s chřipkou. V sezoně 2008/2009 se nechalo naočkovat v ČR asi 700 tisíc lidí, tedy približně sedm procent populace. $V$ řadě měst měl průběh choroby charakter epidemie, tzn. že onemocnělo více než 2000 lidí na 100000 obyvatel.

SZO vždy v únoru každého roku vydává doporučení $\mathrm{k}$ použití výrobních vakcinačních chřipkových kmenů pro následující chřipkovou sezonu. Toto doporučení vychází z analýzy dat poskytovaných více než 100 laboratoří po celém světě. Během roku se chřipkové viry třídí a vybírají se vzorky, které se zasílají do trrí světových center SZO: ve Spojených státech, Anglii a Austrálii. Tímto způsobem se monitorují genetické změny cirkulujících chřipkových kmenů a doporučují se ty, které jsou schopny vytvářet dostatečnou imunitní odpověd' vůči nově zjištěným virovým variantám (Ghendon, 1991).

Současné chřipkové vakcíny obsahují vždy tři virové kmeny, které nejčastěji reprezentují jejich celosvětový výskyt: A/H1N1, A/H3N2 a typ B. Všechny typy inaktivovaných chřipkových vakcín se prípravují pomnožením viru ve slepičích vejcích. Virionové částice se pak inaktivují formaldehydem nebo beta-propionlaktonem. Suspenze inaktivovaných virionů se smíchá s organickým rozpouštědlem nebo detergentem, aby došlo $\mathrm{k}$ porušení lipidové virové obálky a uvolnily se rozpustné povrchové glykoproteiny. Podle dalšího zpracování se pak rozeznávají splitované (štěpené) a subjednotkové vakcíny. Díky své selektivnosti antigenů jsou významně méně reaktogenní a mají méně nežádoucích účinků než vakcíny atenuované (celovirionové) (Grossgebauer et al., 1969).

\footnotetext{
Vakcinace

Epidemiologické a ekonomické dopady chřipky jsou každoročně velmi závažné. Ochrana před chřipkou prostřednictvím vakcinace je jednoduchá a účinná a je klíčovým faktorem pro zvládnutí a průběh epidemie. Obavy před vakcinací jsou zbytečné, současné vakcíny jsou bezpečné a účinné. Vakcinace snižuje významným způsobem počet onemocnění, snižuje počet dnů pracovní neschopnosti a snižuje počet návštěv u lékaře (Chlíbek et al., 2002).
}

\section{Univerzální chřipková vakcína}

Jednotlivé typy chřipkových vakcín mají své přednosti i nedostatky. Jejich největším nedostatkem je skutečnost, že přestávají být účinné, dojde-li náhle $\mathrm{k}$ neočekávané změně chřipkového viru. Výrazným zdokonalením vakcinace proti chřipce by bylo zavedení očkovací látky, která je méně citlivá na vznik antigenních změn. Dosud provedené studie ukazují, že imunologické aktivity namírené proti relativně neměnným virovým strukturám mohou snížit počet onemocnění a úmrtnost na toto onemocnění. Nejslibnější se zdá být relativně stálá doména M2 proteinu (Watanabe et al., 2008). Protein $\mathrm{M} 2$ se podílí na regulaci $\mathrm{pH}$ viru poté, co se virus dostane do hostitelské buňky. Vodíkové ionty procházejí kanálem tvořeným tímto proteinem, vstupují do intersticia virových částic a vyvolají odloučení M1 proteinu, což vede ke vstupu ribonukleoproteinu do buněčného jádra a následně pak $\mathrm{k}$ replikaci viru. M2 protein obsahuje malou neglykosylovanou doménu s 23 aminokyselinami označovanou jako M2e. Tato oblast prokazuje jen malé změny mezi různými typy lidského chřipkového viru typu A. Studie prováděné u myší a fretek prokázaly, že specifické protilátky proti M2e nezabránily infekci, ale omezily replikaci viru, zmírnily průběh onemocnění a snížily úmrtnost (Denis et al., 2008). Dosud provedené zkoušky prokázaly, že antigenní variabilita M2e je minimální a že specifické protilátky M2e omezují replikaci viru in vitro. Nové vakcíny založené na tomto principu by pravděpodobně stimulovaly humorální i Tbuněčnou imunitu a odstranily by nutnost každoročního přeočkování (Eich, 2007).

Př́prava univerzální vakcíny proti chřipce je prozatím ve stadiu experimentálních studií jednotlivých komponent genomu chřipky A. Dosažené výsledky jsou slibné, ale realizace výsledků do praktické vakcinace proti chřipce potrvá ještě řadu let.

\section{LITERATURA}

BENTZ, J., MITTAL, A.: Architecture of the influenza hemagglutinin membrane fusion site. In: Biochim. Biophys. Acta, 2003, Vol. 1614, no. 1, s. 24-35.

BERAN, J., HAVLÍK, J.: Chřipka. Klinický obraz, prevence, léćba. 2. vyd., Praha: Computer Press, 2007. 184 s. BETAKOVA, T.: M2 protein - a proton channel of influenza A virus. In: Curr. Pharm. Des., 2007, Vol. 13, no. 31, s. 3231-3235. 
COLLINS, P. L., BUKREYEV, A., MURPHY, B. R.: What are the risks - hypothetical and observed - of recombination involving live vaccines and vaccine vectors based on nonsegmented negative-strain RNA viruses? In: J. Virol., 2008, Vol. 82, no. 19, s. 9805-9806.

DE MARCO, M. A. et al.: Influenza virus circulation in wild aquatic birds in Italy during $\mathrm{H} 5 \mathrm{~N} 2$ and $\mathrm{H} 7 \mathrm{~N} 1$ poultry epidemic periods (1998 to 2000). In: Avian Pathol., 2005, Vol. 34, no. 6, s. 480-485.

DENIS, J. et al.: Development of a universal influenza A vaccine based on the M2e peptide fused to the papaya mosaic virus (PapMV) vaccine platform. In: Vaccine., 2008, Vol. 26, no. 27-28, s. 3395-3403.

GHENDON, Y.: Influenza surveillance. Bull. In: World Health Organ., 1991, Vol. 69, no. 5, s. 509-515.

GRAY, C., TAMM, L. K.: pH-Induced conformational changes of membrane-bound influenza hemagglutinin and its effect on target lipid bilayer. In: Protein Sci., 1998, Vol. 7, no. 11, s. 2359-2373.

GROSSGEBAUER, K., LANGMAACK, H., SCHMIDT, B., KUCCHLER, R.: Enhancement and neutralisation of pyrogenicity of influenza viruses by biologically active substances. In: Arch. Ges. Virusforsch., 1969, Vol. 28, no. 2, s. $151-164$

HARRISON, S. C.: Viral membrane fusion. In: Nat. Struct. Mol. Biol., 2008, Vol. 15, no. 7, s. 690-698.

HE, C. Q. et al.: Homologous recombination as a evolutionary force in the avian influenta A virus. In: Mol. Biol. Evol., 2009, Vol. 26, no. 1, s. 177-178.
HONGO, S.: Type C influenza. [Article in Japanese]. Nippon Rinsho, 2006, Vol. 64, no. 10, s. 1942-1949.

HOSAKA, Y.: Structure and function of influenza virus neucleoprotein (NP). [Article in Japanese]. In: Nippon Rinsho, 1997, Vol. 55, no. 10, s. 2599-2604.

CHLÍBEK, R., BERAN, J., ŠPLIŇO, M.: Efektivita očkování proti chřipce u zdravých dospělých - čtyřnásobný pokles nemocnosti v jedné chřipkové sezoně. In: Epidemiol. Mikrobiol. Imunol., 2002, Vol. 51, no. 2, s. 4751.

ITOH, M., HOTTA, H.: Structure, function and regulation of expression in influenza virus matrix M1 protein. [Article in Japanese]. In: Nippon Rinsho, 1997, Vol. 55, no. 10 , s. 258-2586.

MAESA, Y., HORIMOTO, T., KAWAOKA, Y.: Classification and genome structure of influenza virus. [Article in Japanese]. In: Nippon Rinsho, 2003, Vol. 61, no. 11, s. $1886-1891$.

NELSON, M. I. et al.: Phylogenetic analysis reveals the global migration of seasonal influenza A viruses. In: PlOS Pathog., 2007, Vol. 3, no. 9, s. 1220-1228.

WATANABE, T. et al.: Novel approach to the development of effective H5N1 influenza A virus vaccines: use of M2 cytoplasmic tail mutants. In: J. Virol., 2008, Vol. 82, no. 5, s. 2486-2492.

YAMAZAKI, Y. et al.: Serological survey of avian H5N2 -subtype influenza virus infections in human populations. In: Arch. Virol., 2009. [Epub ahead of print].

Jiří Patočka 